\title{
Pemberdayaan Masyarakat dalam Pengembangan Desa Wisata di Dusun Plempoh, Desa Bokoharjo, Kecamatan Prambanan, Kabupaten Sleman, D.I Yogyakarta
}

\author{
Bilal Ma'arif, Syakdiah, Oktiva Anggraini \\ Prodi Ilmu Administrasi Negara Fakultas Ilmu Sosial dan Ilmu Politik \\ Universitas Widya Mataram \\ syakdiah8@gmail.com
}

\begin{abstract}
Community empowerment is basically an effort to make people able to actualize themselves in managing the cultural environment that is around them and fulfill their needs independently without dependence on other parties. In relation to cultural heritage, empowerment activities depart from the basic concept that the management of a cultural heritage needs to pay attention to its important value or social significance. In other words, the extent to which a cultural preservation is socially meaningful for its people. The process of empowering the Tourism Village in Plempoh Hamlet, Bokoharjo Village, Prambanan District, Sleman Regency, Yogyakarta. At the beginning of the program, the community awareness stage was carried out by pioneers of village empowerment with makeshift funds and there was no guidance from government agencies. Before Pokdarwis was formed, it was previously called Plempoh Tourism Village in 2010. Only in 2015 did Pokdarwis Plempoh be formed. Efforts made in utilizing the potential and skills possessed for the initial pilot. To identify potential as well as constraints on community empowerment related to the availability of regional cultural resources. Mapping the needs and forms of empowerment programs tailored to the needs of the community and the availability of supporting resources. The initial approach taken was a community-oriented approach in its implementation realized through empowering the community around the site. Broadly speaking, there are four types of technical training held, namely batik training, souvenir making training, culinary training and tour guide training and the development of cultural tourism travel businesses.
\end{abstract}

Key words : community empowerment, tourism village, training

\section{Pendahuluan}

Sektor pariwisata merupakan salah satu sumber devisa negara yang sangat penting dan mampu memberikan sumbangan yang cukup besar dalam perekonomian nasional seperti penyerapan lapangan kerja. Di lain sisi, produk pariwisata massal dewasa ini mulai banyak ditinggalkan dan wisatawan beralih kepada produk wisata alam. Satu jenis pariwisata yang lebih menghargai lingkungan, alam, budaya dan atraksi secara spesial. Kepuasan wisatawan tidak hanya bersandar 
pada keindahan alam dan kelengkapan fasilitas wisata melainkan juga pada keleluasaan dan intensitas interaksi dengan lingkungan dan masyarakat lokal.

Indonesia sebagai negara kepulauan dengan kekayaan alam dan keberagaman bangsa, menyimpan potensi dan peluang berharga untuk membangun kepariwisataan. Untuk lebih menggairahkan dunia kepariwisataan, pemerintah memiliki peranan penting dalam menggali potensi dan membuat kebijakan sehingga masyarakat lokal tergugah kesadarannya untuk menggali potensi dan bergerak membangun desa maupun kota masing-masing.

Sebagai salah satu desa wisata yang berpotensi di wilayah Sleman, Plempoh memberikan kontribusi yang tidak sedikit bagi masyarakat sekitarnya. Obyek wisata disekitar Plempoh menawarkan suasana pedesaaan yang mengingatkan para wisatawan akan nuansa alami dan tradisional. Potensi alam dan budaya yang dimiliki Desa Plempoh memberikan dampak positif bagi pembukaan lapangan pekerjaan baru dan peningkatan kesejahteraan ekonomi warga setempat. Sebelumnya, di desa wisata ini, masyarakat hanya mengandalkan mata pencaharian sebagai petani.

Dalam porsi yang lebih kecil kegiatan-kegiatan dalam usaha pendukung pariwisata juga banyak digeluti sebagai mata pencaharian, seperti pada bidang pembuatan produk kerajinan, perdagangan kerajinan, penginapan, hotel, warung makan, ataupun angkutan. Sebagai basis kegiatan ekonomi, khususnya pariwisata memberikan dampak positif bagi masyarakat sekitar. Aktivitas ekonomi pariwisata yang berkembang pesat secara tidak langsung menciptakan mata rantai kegiatan ekonomi lainnya. Berbagai usaha ekonomi yang dijalankan warga masyarakat semakin bervariasi, tidak hanya bersifat langsung dengan pariwisata, tetapi juga yang bersifat tidak langsung. Kebutuhan ruang untuk kegiatan ekonomi semakin bertambah ketika berbagai kegiatan atau usaha ekonomi pariwisata semakin ekspansif. Secara kuantitatif tercatat jumlah pengunjung terus meningkat secara signifikan. Di pihak lain, kegiatan-kegiatan ekonomi yang muncul bersamaan dengan perkembangan pariwisata di satu sisi dapat memberikan kontribusi positif terhadap peningkatan penghidupan masyarakat, namun disisi lain, jika tidak dikelola dengan baik, ia akan berdampak buruk terhadap kelestarian lingkungan. Sebenarnya pengelolaan yang tepat dan disertai dengan penguatan kesadaran masyarakat akan arti penting benda cagar budaya dapat dilakukan untuk memberikan efek pemanfaatan dan pelestarian dalam satu kesatuan yang utuh.

Dari sudut pandang ekonomi, adanya warisan budaya ini seharusnya mampu mendorong pertumbuhan ekonomi, salah satunya melalui pengembangan pariwisata. Seperti yang dapat diperhatikan pada kawasan Komplek Candi Prambanan dan Ratu Boko dengan adanya pembangunan pariwisata sudah mampu mendorong perekonomian warga setempat. Di pihak lain, ditemukan kegiatan yang mengancam kelestarian kawasan. Kegiatan penambangan batu putih, salah satunya yang berlangsung di tidak jauh dari 
Situs Candi Ijo telah menjadi salah satu sumber penghasilan warga setempat. Situasi ini sering kali menimbulkan dilema dalam hal pengelolaan kawasan cagar budaya sekitar Prambanan. Termasuk adanya jual beli lahan yang dilakukan warga setempat kepada para invenstor yang tertarik untuk menanamkan modalnya dikawasan pegunungan seribu (Sewu Plateau) karena dinilai memiliki pesona bentang alam (landscape) yang menarik. Belum lagi persoalan lain terkait kesadaran atau masih adanya sikap acuh, tidak mau tahu dari masyarakat sekitar akan arti penting warisan budaya. Situasi seperti ini dimungkinkan terjadi karena masyarakat setempat belum menyadari dan mendapatkan manfaat secara langsung keberadaan bendabenda cagar budaya.

Berangkat dari pandangan, bahwa masyarakat adalah pemilik sah warisan budaya, maka masyarakat lokal yang bermukim di sekitar situs penting diposisikan sebagai salah satu sumber pertimbangan utama dalam segala kegiatan yang menyangkut persoalan warisan budaya. Model alternatif yang dikembangkan masyarakat diberi peran yang lebih besar untuk ikut serta menentukan pengelolaan sumber daya arkeologi di daerahnya.Posisi pemerintah tidak lagi ditempatkan sebagai penentu kebijakan tunggal, melainkan lebih banyak berperan sebagai fasilitator. Pendekatan yang berorientasi masyarakat dalam implementasinya diwujudkan melalui pemberdayaan masyarakat di sekitar situs. Pendekatan ini mempunyai keuntungan bagi kedua belah pihak, antara pihak pengelola warisan budaya dengan pihak masyarakat di sekitar situs. Pihak pengelola, yakni pemerintah dalam upaya pelestarian memperoleh dukungan dari masyarakat, karena mereka membutuhkan peran dari warisan tersebut.

Pemberdayaan yang dilakukan di masyarakat perlu disesuaikan dengan potensi yang telah dimiliki. Perlu adanya dorongan agar potensi yang dimiliki oleh masyarakat dapat berkembang dengan baik dan memberikan nilai tambah bagi kehidupan masyarakat di pedesaan. Banyak potensi yang berkembang di masyarakat, salah satunya potensi dalam sektor pariwisata. Dengan potensi wisata yang dimiliki, suatu daerah pedesaan dapat diberdayakan menjadi desa wisata

Pendekatan berorientasi pada keterlibatan masyarakat yang diimplementasikan dalam bentuk pemberdayaan, merupakan langkah resolusi yang diperkirakan mampu meredam atau bahkan menghilangkan konflik pemanfaatan warisan budaya selama ini. Berangkat dari latar belakang di atas maka menarik untuk diteliti lebih lanjut tentang strategi pengembangan desa wisata melalui pemberdayaan masyarakat Dusun Plempoh, Desa Bokoharjo, Kecamatan Prambanan, Kabupaten Sleman.

\section{Konsep Pemberdayaan Masyarakat Desa}

Undang-Undang No 6 Tahun 2014 Tentang Desa menjelaskan bahwa Pemberdayaan Masyarakat Desa adalah upaya mengembangkan kemandirian dan kesejahteraan masyarakat dengan 
meningkatkan pengetahuan, sikap, ketrampilan, perilaku, kemampuan, kesadaran serta memanfaatkan sumber daya melalui penetapan kebijakan, program, kegiatan, dan pendampingan yang sesuai dengan esensi masalah dan prioritas kebutuhan masyarakat desa. Lahirnya UU No 6 Tahun 2014 Tentang Desa mengembangkan paradigma dan konsep baru kebijakan tata kelola desa secara Nasional.UU Desa mengembangkan prinsip keberagaman, mengedepankan asas rekognisi dan subsidiaritas desa. Lain daripada itu UU Desa mengangkat hak dan kedaulatan desa yang terpinggirkan karena didudukkan pada posisi sub nasional ( Kurniawan, 2015 : 9).

Desa yang maju, kuat, mandiri, demokratis dan sejahtera merupakan imajinasi tentang desa baru yang ditegaskan dalam UU desa.Perubahan pada hakekatnya memang tidak mudah tetapi juga tidak terlalu sulit. Oleh karena itu, pemerintah melalui berbagai program untuk mendorong pembangunan desa melalui pemberdayaan masyarakat desa.

Masyarakat yang menjadi anggota dalam kelompok sadar wisata desa Plempoh merupakan suatu kelompok. Kelompok disini dapat diartikan sebagai suatu sistem yang terdiri dari sejumlah orang yang berinteraksi satu sama lain dan terlibat dalam suatu kegiatan bersama. Dalam hal ini kelompok adalah suatu kesatuan sosial yang terdiri atas dua atau lebih individu yang telah mengadakan interaksi sosial yang cukup intensif dan teratur, sehingga diantara individu sudah terdapat pembagian tugas, struktur dan normanorma tertentu yang khas bagi ketentuan sosial tersebut.

\section{Strategi Pengembangan Desa Wisata}

Dengan strategi yang tepat, melalui penggunaan sumber-sumber kekuasaan di daerah secara efektif, akan menghasilkan kelompok sasaran yang dapat keluar dari dominasi dan ketidakberdayaan. Pemberdayaan dapat dilakukan melalui tiga aras atau matra pemberdayaan (empowerment setting):

1. Aras Mikro. Pemberdayaan dilakukan terhadap klien secara individu melalui bimbingan, konseling, stress management, crisis intervention. Tujuan utamanya adalah membimbing atau melatih klien dalam menjalankan tugas-tugas kehidupannya. Model ini sering disebut sebagai Pendekatan yang Berpusat pada Tugas (Task Centered Approach).

2. Aras Mezzo. Pemberdayaan dilakukan terhadap sekelompok Klien.Pemberdayaan dilakukan dengan menggunakan kelompok sebagai media intervensi. Pendidikan dan pelatihan, dinamika kelompok, biasanya digunakan sebagai strategi dalam meningkatkan kesadaran, pengetahuan, keterampilan dan sikap-sikap klien agar memiliki kemampuan memecahkan permasalahan yang dihadapinya.

3. Aras Makro: Pendekatan ini disebut juga sebagai Strategi Sistem Besar (large-system strategy), karena sasaran perubahan diarahkan pada sistem lingkungan yang lebih luas. Perumusan kebijakan, perencanaan sosial, kampanye, aksi sosial, lobbying, pengorganisasian masyarakat, manajemen konflik, adalah beberapa 
Bilal Ma'arif, Syakdiah, Oktiva Anggraini, Pemberdayaan Masyarakat dalam ...

strategi dalam pendekatan ini. Strategi Sistem Besar memandang klien sebagai orang yang memiliki kompetensi untuk memahami situasi-situasi mereka sendiri dan untuk memilih serta menentukan strategi yang tepat untuk bertindak (Suharto, 2005; 66).

\section{Konsep Kelembagaan Desa}

Konseptualisasi pembangunan dari desa berangkat dari pemahaman bahwa desa merupakan unit masyarakat yang terorganisir dan telah teruji dalam mengurusi dirinya sendiri. Konsep ini popular dengan istilah otonomi asli. Desa merupakan level pemerintah terendah dinegara kita dan memiliki ciri khas yang sangat unik. Ciri khas desa yang unik tersebut semakin menguatkan asumsi kita bahwa strategi pembangunan dari desa merupakan strategi pembangunan yang dapat menyelaraskan antara tujuan pemerataan pembangunan pertumbuhan ekonomi dan tercapainya stabilisasi pemerintahan.

$$
\text { Pengembangan kelembagaan }
$$

merupakan salah satu alternatif yang dilakukan pemerintah untuk menciptakan organisasi yang cerdas, lincah,gesit dalam menyikapi berbagai perubahan perubahan. Agar organisasi birokrasi tersebut mampu eksis dan bertahan dalam melaksanakan tugas dan tanggungjawab maka pilihan untuk selalu melakukan penyesuaian terhadap perubahan dalam pola kerja tidak dapat dihindarkan. Penguatan kelembagaan pembangunan di sektor lembaga publik didefinisikan sebagai seluruh perencanaan, pembuatan struktur dan petunjuk-petunjuk baru dalam penataan kembali haluan organisasi yang meliputi:

1. Membuat, mendukung dan memperkokoh hubungan normatif dan pola-pola yang aktif.

2. Pembentukan fungsi-fungsi dan jasa yang dihargai oleh masyarakat.

3. Penciptaan fasilitas yang menghubungkan antara teknologi baru dengan lingkungan sosial.

Freed W. Rigg memberikan beberapa konsep riset yang dihasilkan oleh Inter-University Riset program tentang pembangunan lembaga, yang menghasilkan 3 (tiga) katagori dasar analisa yaitu (Freed W. Rigg dalam Badrul Munir, 2001):

1. Istilah lembaga merupakan suatu variabel yang menerangkan perilaku lembaganya sendiri. Didalamnya terdapat sub kategori seperti kepemimpinan, doktrin, program, sumber daya dan struktur internal.

2. Istilah tersebut menerangkan transaksi yang terdapat dalam sub kategori seperti :kemampuan memperoleh dukungan untuk mengatasi hambatan yang akan datang dan pemindahan norma-norma serta nilai.

3. Analisa lingkaran atau mata rantai kelembagaan yang menunjukkan saling ketergantungan antara lembaga dan bagian bagian yang relevan dalam masyarakat serta pendayagunaan dan memfungsikan dari segi normatif.

Birokrasi sebagai organisasi (lembaga) pemerintahan baik di tingkat pusat maupun di daerah dalam melaksanakan tugas pokok dan 
fungsi mendasarkan diri pada pengaturan dan wewenang sebagai berikut (Martin Albrow, 2001:30):

1. Kegiatan-kegiatan yang bersifat rutin tiaptiap organisasi ditetapkan sebagai "tugastugas resmi”.

2. Tugas-tugas relatif bersifat stabil artinya tidak mengalami perubahan-perubahan yang berarti dan wewenang untuk melaksanakan itu sepenuhnya terikat pada aturan yang berlaku.

3. Ada keteraturan baik dalam mekanisme maupun prosedur, cara-cara yang sudah baku untuk menjamin kelangsungan pelaksanaan tugas-tugas pegawai yang memenuhi kualifikasi menurut ketentuanketentuan yang berlaku.

\section{Pengertian Kelompok Sadar Wisata}

Kelompok Sadar Wisata (Pokdarwis) merupakan salah satu alternatif pengembangan pariwisata terkait dengan kampanye sadar wisata. Pengembangan pariwisata nusantara yang dilakukan Kelompok Sadar Wisata (Pokdarwis) melalui berbagai kegiatan antara lain pembinaan masyarakat melalui kelompok swadaya dan swakarsa masyarakat yang berfungsi sebagai penggerak pembangunan pariwisata. Kelompok sadar wisata adalah sekumpulan warga masyarakat yang mempunyai kaitan mata pencarian dari aktivitas wisata membentuk suatu wadah. Kelompok ini bersifat informal sebagai wadah bertukar pikiran, kegiatan, pembicaraan dan pengembangan dalam rangka mencapai tujuan agar wilayah mereka menjadi wilayah yang mempunyai daya tarik wisata. Kelompok sadar wisata adalah sarana penyalur aspirasi dan komunikasi sosial antar pengurus dan warga sehingga permasalahan untuk menciptakan wilayah yang bersih, indah, aman dapat terlaksana.

Pada hakikatnya pengembangan desa wisata dilakukan melalui perencanaan dan pelaksanaan kegiatan kepariwisataan berdasarkan keanekaragaman, keunikan dan kekhasan tradisi seni budaya dan kearifan lokal setempat serta memperhatikan kelestarian lingkungan hidup disekitarnya (PP tentang Desa tahun 2014). Pengembangan desa wisata tersebut meliputi pembangunan :

1. Industri pariwisata.

2. Destinasi pariwisata.

3. Kelembagaan kepariwisataan.

4. Promosi dan pemasaran .

\section{Metode penelitian}

Metode penelitian digunakan dalam penelitian ini yaitu metode kualitatif dengan menggunakan deskriptif analisis.Penelitian deskriptif adalah jenis penelitian yang berkaitan dengan pengumpulan data (baik tertulis maupun lisan) untuk memberikan gambaran atau penegasan suatu fenomena atau gejala secara lengkap dalam aspek yang diselidiki dan dikembangkan dengan memberikan penafsiran terhadap data objek yang ditemukan (Bogdan dan Taylor,1992).Pendekatan penelitian kualitatif, menurut Bogdan dan Taylor dalam Moleong (2011: 4), penelitian kualitatif sebagai prosedur penelitian yang menghasilkan data deskriptif berupa kata-kata tertulis atau lisan 
dari orang-orang dan perilaku yang dapat diamati.

\section{Pembahasan}

Pemberdayaan masyarakat sebenarnya mengacu pada kata empowerment, yaitu sebagai upaya untuk mengaktualisasikan potensi yang sudah dimiliki masyarakat. Pemberdayaan masyarakat merupakan suatu proses atau cara untuk meningkatkan taraf hidup atau kualitas masyarakat. Melalui suatu kegiatan tertentu, yaitu melakukan kegiatan yang bertujuan meningkatkan kualitas SDM, yang disesuaikan dengan keadaan dan karakteristik di masyarakat itu sendiri.Pemberdayaan potensi lokal merupakan bagian penting menuju kemandirian masyarakat yang memiliki keragaman sumber daya , baik sosial, budaya, ekonomi dan lingkungan. Desa wisata sangat terkait dengan kebutuhan masyarakat setempat dengan mendayagunakan potensi lokal yang terorganisir. Pengelola Desa Wisata yang baik dapat memberikan peluang yang besar pada masyarakat desa dalam rangka mendayagunakan dan mengembangkan potensi lokal guna mewujudkan mutu kehidupan masyarakat yang lebih baik, sejahtera dan mandiri, atau dengan kata lain Desa Wisata yang dikelola dengan baik dapat mendorong tumbuh dan berkembangnya kegiatan ekonomi masyarakat desa.

Sadar wisata merupakan bentuk partisipasi dan dukungan masyarakat dalam mendorong terwujudnya iklim yang kondusif bagi tumbuh dan berkembangnya kegiatan kepariwisataan di suatu tempat atau wilayah. Dalam hal ini penting bagi seluruh masyarakat menjadi pendukung dan juga menjadi bagian dari kegiatan pariwisata di mana keterlibatan seluruh unsur masyarakat akan berdampak pada nilai daya tarik dan kekuatan dalam pengelolaan dan pengembangan pariwisata di masing - masing wilayah.Warga yang berprofesi sebagai petani rata - rata memiliki lahan di wilayah bagian bawah dusun Plempoh atau di lereng - lereng tebing. Sedangkan yang beternak banyak yang menggembalakan ternaknya di kawasan candi contohnya di sekitar Candi Boko. Sehingga Candi Boko terlihat terkesan kurang rapi karena banyak ternak warga yang berkeliaran di dalam kawasan candi. Rata - rata generasi muda di desa lebih memilih bekerja di kota karena jumlah lowongan pekerjaan lebih banyak daripada berada di desa serta gaji yang lebih banyak. Sebenarnya warga desa sangat tergantung pada bertani dan beternak saja. Padahal bila dilihat dari dekatnya desa dengan beberapa situs cagar budaya dan potensi lainnya maka seharusnya tingkat taraf ekonomi masyarakat desa bisa meningkat. Proses penyadaran yang dilaksanakan oleh para pelopor pemberdayaan kepada warga yang mendukung maupun yang tidak mendukung dilakukan secara persuasif baik secara individu maupun kelompok.

Peran aparat Desa setempat, pemerintah dan masyarakat menjadi penggerak kegiatan pengembangan desa wisata. Unsur modal sosial sangat penting dalam masyarakat. Hal ini ditandai dengan masyarakat yang harmonis, yang menjadi salah satu syarat bagi berlanjutnya pemberdayaan wisata di Desa Plempoh. Salah satunya dengan rembug warga 
desa, selanjutnya dapat diperoleh beberapa gagasan peluang pengembangan yang sekiranya dapat dikerjakan warga. Pihak yang ikut serta dalam proses penyadaran masyarakat adalah pihak Balai Pelestarian Cagar Budaya (BPCB). Tiga aspek utama yang akan dikembangkan secara bertahap dipilih berdasarkan kajian yang sudah dilakukan pihak BPCB. Pertama adalah persoalan pemahaman masyarakat terhadap pelestarian cagar budaya sebagaimana tertuang dalam Undang-Undang Nomor 11 Tahun 2010 Tentang Cagar Budaya. Pemahaman ini penting mengingat dasar hukum semua aktivitas yang terkait dengan cagar budaya telah diatur dalam undang-undang ini. Kedua adalah persoalan pemahaman masyarakat mengenai peran penting kelembagaan dan aspek-aspek kepariwisataan. Program yang diselenggarakan yaitu upaya pendampingan membentuk lembaga berbadan hukum agar dapat memperkuat posisi mereka dalam pengembangan potensi cagar budaya di lingkungan mereka sebagai objek pariwisata. Ketiga adalah bekal keahlian dan keterampilan perlu diberikan kepada masyarakat sebagai modal utama dalam memanfaatkan pengembangan pariwisata budaya. Bila disimpulkan maka semuanya akan tergambar seperti pada gambar dibawah ini.

\section{Gambar 1}

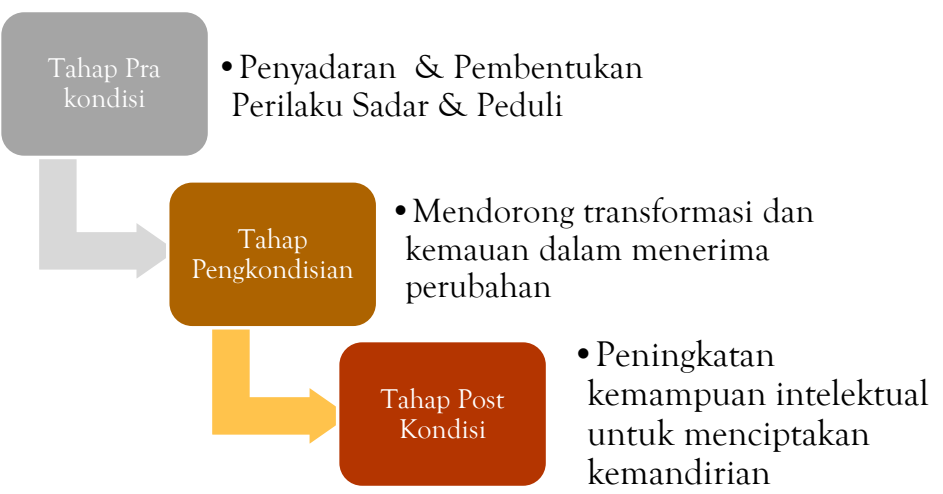

Peran Ketua Pokdarwis dan Kepala Dusun dalam proses pemberdayaan masyarakat cukup besar dalam memajukan Dusun dan masyarakat setempat demi mensukseskan Plempoh menjadi salah satu Desa Wisata di wilayah Kabupaten Sleman . Upaya pemberdayaan dapat berjalan dengan baik dan bisa mencapai tujuan yang diinginkan , perlu adanya peran dari pemerintah dan Swasta. Peran dari ketiga aktor yaitu pemerintah, swasta dan masyarakat tidak bisa dipisahkan karena peran mereka saling berhubungan satu sama lain, jika ada satu aktor yang tidak melakukan peran dengan baik maka upaya pemberdayaan akan sulit dilakukan.

Pengembangan kegiatan budaya dan pariwisata merupakan kegiatan yang berbasis komunitas yaitu sumberdaya dan keunikan komunitas lokal baik berupa elemen fisik maupun non fisik (nilai-nilai, norma-norma, adat dan tradisi) yang melekat pada komunitas 
tersebut merupakan unsur penggerak utama kegiatan budaya dan tradisi masyarakat itu sendiri. Pengembangan sumberdaya budaya dan pariwisata harus sensitif dan responsif terhadap keberadaan dan kebutuhan komunitas lokal.Program awal yang terselenggara adalah dari pemerintah desa bersama pihak BPCB mengadakan rembug warga Desa Bokoharjo yang dilaksanakan di Balai Desa Bokoharjo, Prambanan pada pertengahan tahun 2015. Kegiatan diikuti perwakilan peserta yang terdiri atas: perwakilan desa wisata Plempoh, perwakilan warga dari 3 dusun (Dusun Gatak, Dusun Cepit dan Dusun Dawung), Pelaku kesenian dan perangkat desa. Pertemuan dibuka PLH Kepala Desa Bokoharjo. Pada kesempatan tersebut Kepala Desa Bokoharjo menyampaikan keinginan pengembangan pariwisata di lingkungan sekitar Ratu Boko untuk dapat lebih ditingkatkan sebagai salah satu peluang ekonomi bagi masyarakat, mengingat selama ini pariwisata belum dirasakan secara langsung masyarakat sekitar.
Keberadaan situs Ratu Boko sebagai salah satu warisan bersejarah menjadi salah satu ikon bagi wilayah Sleman khususnya dan bagi DIY pada umumnya, namun seperti yang diungkapkan sebagian warga bahwa pengelolaan candi yang dilakukan PT Taman Wisata Prambanan Ratu Boko, menurut mereka belum banyak memberikan dampak dan pelibatan masyarakat. Namun demikian hal itu juga diakui sebagai akibat dari adanya minimnya keterampilan warga.

Pendekatan yang harus dilakukan adalah pendekatan yang berorientasi masyarakat dalam implementasinya diwujudkan melalui pemberdayaan masyarakat di sekitar situs. Pendekatan ini mempunyai keuntungan bagi kedua belah pihak, antara pihak pengelola warisan budaya dengan pihak masyarakat di sekitar situs. Pihak pengelola, yakni pemerintah dalam upaya pelestarian memperoleh dukungan dari masyarakat karena mereka membutuhkan peran dari warisan tersebut. 
Tabel 1

Potensi dan Kendala

\begin{tabular}{|l|l|l|}
\hline Potensi & Jenis Potensi & Fakta Kondisi Eksisting \\
\hline Alam & $\begin{array}{l}\text { Lanskap kawasan } \\
\text { Ratu Boko }\end{array}$ & $\begin{array}{l}\text { Jalan (akses) ke obyek di } \\
\text { beberapa bagian rusak dan terjal }\end{array}$ \\
\hline Budaya & $\begin{array}{l}\text { Kompleks Situs } \\
\text { Ratu Boko }\end{array}$ & $\begin{array}{l}\text { Kompleks Situs Ratu Boko saat } \\
\text { ini dikelola oleh PT Taman } \\
\text { Wisata } \\
\text { Candi Banyunibo merupakan } \\
\text { Candi Banyunibo yang terletak di tengah }\end{array}$ \\
\hline Kesenian & $\begin{array}{l}\text { Seni tradisional: } \\
\text { Srandul, } \\
\text { campursari }\end{array}$ & $\begin{array}{l}\text { Ada potensi, bahkan gamelan } \\
\text { juga sudah ada, namun dari sisi } \\
\text { kelembagaan perlu ditingkatkan. } \\
\text { Bahkan, beberapa kali sudah } \\
\text { ditampilkan pada objek wisata }\end{array}$ \\
\hline Kerajinan & $\begin{array}{l}\text { Bahan limbah } \\
\text { kayu, } \\
\text { andesit }\end{array}$ & $\begin{array}{l}\text { Belum ada di busun Cepit } \\
\text { mengembangkan, baik kuliner } \\
\text { maupun benda kerajinan }\end{array}$ \\
\hline
\end{tabular}

Sumber: BPCB, Yogyakarta, 2015.

Pada tabel 1 diatas terlihat apa saja potensi dan juga kendala yang ada pada desa Plempoh. Beragam jenis dan potensi yang dapat dikemas seperti kesenian, kerajinan, maupun kegiatan kemasyarakatan untuk menjadikan desa Plempoh sebagai salah satu daya tarik wisata. Selama ini warga masyarakat di sekitar kawasan memang hanya memiliki keterampilan dalam mengolah berbagai macam sumber daya alam yang dimiliki, seperti buah mangga, ubi, gadung dan lain lain.
Pada dasarnya desa wisata Plempoh adalah sebuah desa yang layak ditetapkan sebagai desa wisata oleh pemerintah, disebabkan desa ini memang kaya akan potensi sumber alam, budaya dan seni tradisi, namun dikarenakan pengelolaan manajemen dari desa wisata ini yang belum baik maka mengakibatkan desa wisata tersebut menjadi lebih terpuruk. Misalnya seperti kesenian karawitan yang sudah ada tetapi belum sama sekali mendapatkan pelatihan dan pengembangan dari pemerintah setempat. 
Faktor terbesar yang membuat desa wisata ini kurang berkembang adalah kurangnya SDM terlatih yang mampu mengembangkan potensi wisata desa ini, selain itu ditambah lagi adanya kecurangan yang dilakukan oleh para pengelola desa wisata ini semisal kurang terbukanya pengurus terdahulu dalam hal keuangan.

Peran pemerintah di Indonesia disamping berfungsi utama sebagai regulator dalam menentukan norma, standar, prosedur dan kriteria pengembangan kepariwisataan, juga masih terlibat secara langsung dalam manajemen pengembangan kepariwisataan. Proses pemberdayaan nantinya bisa dilakukan melalui beberapa tahap :

1. Sosialisasi program pemberdayaan.

2. Bekal informasi pemberdayaan.

3. Motivasi atau konsultasi.

4. Aksi atau kolaborasi.

Kajian yang dilakukan antara pihak BPCB bekerja sama dengan Pusat Studi Pariwisata Universitas Gadjah Mada merupakan dasar utama dalam menentukan program-program untuk masyarakat di Bokoharjo. Kajian tersebut mencerminkan proses awal pemanfaatan potensi dan ketrampilan masyarakat. Pemberdayaan masyarakat yang dilakukan mengadopsi konsep community based development dengan menempatkan masyarakat sebagai subjek pembangunan. Proses tersebut bersifat bottomup dengan mempertimbangkan harapanharapan, keinginan-keinginan dan persoalanpersoalan yang timbul dan dihadapi masyarakat terkait dengan keberadaan cagar budaya di sekitar mereka. Dengan demikian, penyusunan program dilakukan atas inisiatif dan kepentingan masyarakat. Program tersebut antara lain :

1. Pelatihan membatik dengan motif-motif khas candi-candi dan pengembangan kuliner.

2. Pelatihan membuat souvenir diprioritaskan untuk laki-laki, khususnya pemuda.

3. Pelatihan menjadi pemandu wisata dan pembuatan paket-paket wisata.

Pelatihan-pelatihan yang diselenggarakan selalu melibatkan ahli-ahli yang kompeten dibidangnya masing-masing dan melibatkan juga institusi-institusi terkait. Adapun perinciannya sebagai berikut:

1. Kegiatan sosialisasi undang-undang cagar budaya.

2. Pelatihan tentang kelembagaan dan kepariwisataan.

3. Pelatihan membatik tingkat dasar.

4. Pelatihan membuat cetakan souvenir.

5. Pelatihan kuliner bekerja sama dengan Jurusan Tata Boga UNY.

6. Pelatihan pemandu dan pembuatan paketpaket wisata. 
Tabel 2

Rancangan Program Pemberdayaan Masyarakat

\begin{tabular}{|c|c|c|c|}
\hline Bidang & Sasaran & $\begin{array}{l}\text { Detail Kegiatan } \\
\text { Pemberdayaan }\end{array}$ & Pihak Terkait \\
\hline Hukum & $\begin{array}{l}\text { Masyarakat Desa } \\
\text { Bokoharjo }\end{array}$ & $\begin{array}{l}\text { 1. Pelatihan peningkatan } \\
\text { kapasitas masyarakat tentang } \\
\text { cagar budaya (sosialisasi UU } \\
\text { dan pemanfaatan potensi BCB } \\
\text { untuk wisata) } \\
\text { 2. Bimtek pengetahuan atas } \\
\text { benda cagar budaya kawasan } \\
\text { Ratu Boko dan sekitarnya }\end{array}$ & $\begin{array}{lr}\text { Balai } & \text { Pelestarian } \\
\text { Cagar } & \text { Budaya } \\
\text { Yogyakarta }\end{array}$ \\
\hline Kepariwisataan & $\begin{array}{l}\text { Pengelola desa } \\
\text { wisata } \\
\text { Aparat desa }\end{array}$ & $\begin{array}{l}\text { 1. Bimtek kelembagaan } \\
\text { POKDARWIS (materi } \\
\text { POKDARWIS dan SADAR } \\
\text { WISATA) } \\
\text { 2. Bimtek penyusunan paket } \\
\text { wisata } \\
\text { 3. Bimtek kepemanduan } \\
\text { 4. Pelatihan Bahasa Inggris } \\
\text { pariwisata } \\
\text { 5. Bimtek pemasaran pariwisata } \\
\text { desa }\end{array}$ & $\begin{array}{l}\text { Puspar UGM } \\
\text { Praktisi pemandu }\end{array}$ \\
\hline Ekonomi Kreatif & $\begin{array}{l}\text { Ibu-ibu kelompok } \\
\text { perajin/kuliner }\end{array}$ & $\begin{array}{l}\text { 1. Pelatihan suvenir (berbahan } \\
\text { limbah batu) } \\
\text { 2. Pelatihan kuliner (produksi } \\
\text { dan pengemasan produk) }\end{array}$ & Praktisi kerajinan \\
\hline Seni Budaya & $\begin{array}{l}\text { Pelaku kesenian } \\
\text { Pelaku wisata }\end{array}$ & $\begin{array}{l}\text { 1. Pengembangan kelompok } \\
\text { kesenian } \\
\text { 2. Bimtek manajemen event }\end{array}$ & Praktisi event \\
\hline Kewirausahaan & $\begin{array}{l}\text { Ibu-ibu kelompok } \\
\text { perajin/kuliner } \\
\text { Pelaku wisata } \\
\text { Pelaku kesenian }\end{array}$ & $\begin{array}{l}\text { 1. Pelatihan kewirausahaan } \\
\text { 2. Pelatihan pelayanan prima }\end{array}$ & Praktisi wirausaha \\
\hline
\end{tabular}

Sumber: BPCBYogyakarta, 2015 
Berpijak dari potensi serta peluang pengembangan yang sangat mungkin dikembangkan di Desa Plempoh, selanjutnya secara partisipatif, tim BPCB bersama masyarakat berhasil menyusun rancangan program pemberdayaan masyarakat Desa Plempoh seperti pada tabel diatas.

\section{Tahapan pengembangan desa wisata}

\section{Berbagai bentuk upaya yang dilakukan untuk pengembangan desa wisata}

Pemberdayaan dapat diartikan sebagai tujuan dan proses. Sebagai tujuan, pemberdayaan merupakan suatu keadaan yang ingin dicapai yakni masyarakat yang memiliki kekuatan atau kekuasaan dan keberdayaan yang mengarah pada kemandirian sesuai dengan tipe tipe kekuasaan yang disebutkan sebelumnya. Upaya pemberdayaan ekonomi masyarakat tidak terlepas dari perluasan kesempatan kerja dan peningkatan pendapatan masyarakat . Terkait dengan pemberdayaan masyarakat dalam memperluas kesempatan kerja, maka dipengaruhi salah satunya oleh kebijakan pengembangan usaha kecil. Salah satu hal yang dapat mendukung berkembangnya usaha kecil dan agar tercipta perekonomian yang kokoh adalah faktor modal.Salah satu kegiatan pemberdayaan masyarakat yang diselenggarakan oleh PUSPAR UGM adalah membekali masyarakat dengan keterampilan dan keahlian yang dapat dimanfaatkan untuk memperkaya budaya lokal dan menyambut pariwisata budaya di desa mereka masing-masing.
Pendampingan yang diberikan stakeholder dalam upaya pengembangan desa wisata

Program-program pemberdayaan dijalankan melalui kerja sama dengan agen-agen utama dalam masyarakat di Bokoharjo, termasuk perangkat desa dan dusun, tokoh-tokoh masyarakat, tokoh-tokoh pemuda, dan juga tokoh-tokoh perempuan perlu dilaksanakan. Kegiatan yang sifatnya sosialisasi atau transfer pengetahuan dan pemahaman tentang implementasi undang-undang tentang cagar budaya, kelembagaan dan kepariwisataan, tokoh-tokoh desa ini dilibatkan dan dijadikan peserta utama. Sementara untuk kegiatankegiatan pelatihan, tokoh-tokoh desa tersebut melalui Kelompok Sadar Wisata (Pokdarwis) yang telah terbentuk seiring dengan proses kajian dan sosialisasi berlangsung diminta pertimbangannya dalam menentukan orangorang di sekitar desa yang dianggap potensial untuk berkembang apabila diberikan pelatihanpelatihan teknis untuk mengembangkan keahlian dan keterampilan.

Pendampingan yang dilakukan salah satunya yakni dari PUSPAR UGM .Secara garis besar, terdapat empat jenis pelatihan teknis yang diselenggarakan, yaitu :

1. Pelatihan Membatik

2. Pelatihan Membuat Souvenir.

3. Pelatihan Kuliner.

4. Pelatihan Pemandu Wisata dan Pengembangan Usaha Perjalanan Pariwisata Budaya 
Untuk kedepannya Desa Wisata Plempoh akan bekerjasama dengan PT Taman Wisata Candi Borobudur, Prambanan dan Ratu Boko untuk meminta fasilitas 1 buah kios untuk memasarkan hasil kerajinan batik, souvenir dan kuliner (katul ayu). Ini dijembatani oleh kantor BPCB DI Yogyakarta untuk dapat direalisasikan kios ini guna meningkatkan perekonomian warga sekitarnya. Dalam pameran seluruh Pokdarwis di Bukit Breksi tanggal 21 Juni 2018 kemarin, harga bahan kain batik yang ditawarkan mulai Rp.150.000, Rp. 500.000 dan Rp. 700.000 yang berarti pendapatan warga bertambah dari membatik.

Pokdarwis Prabu Boko juga setiap malam minggu mengadakan latihan karawitan, dan setiap satu bulan sekali ditunjukan di panggung pertunjukan yang berlokasi di dekat pintu masuk obyek wisata Ratu Boko. Selain pertunjukan karawitan, juga dipentaskan atraksi jatilan yang pemainnya adalah warga masyarakat sekitar situs Ratu Boko dan sebagian besar adalah anggota dari Pokdarwis Pabu Boko. Untuk pementasan kesenian jatilan ini setiap 1 minggu sekali terutama pada hari minggu dan juga pada hari-hari libur besar nasional, sesuai kerjasama dengan PT Taman Wisata Ratu Boko. Peningkatan kapasitas pemanduan bagi guide lokal dilakukan dengan pelatihan pemandu wisata dan pengembangan usaha perjalanan wisata budaya yang peserta diberi bekal pemanduan wisata dan penyusunan paket wisata budaya disekitar kawasan Prambanan.

\section{Kesimpulan}

1. Tahapan penyadaran masyarakat.

a. Pada awal program tahap penyadaran masyarakat dilakukan oleh para pelopor pemberdayaan desa dengan dana seadanya dan belum adanya bimbingan dari instansi pemerintah. Sebelum terbentuk Pokdarwis pada tahun 2015 sebelumnya bernama Desa Wisata Plempoh pada tahun 2010. Baru pada tahun 2015 terbentuklah Pokdarwis Plempoh. Pendekatan awal, pendekatan berorientasi masyarakat, implementasinya melalui pemberdayaan masyarakat di sekitar situs.

b. Bentuk kontribusi dari pihak stakeholder dalam proses penyadaran masyarakat. Pihak yang ikut serta dalam proses penyadaran masyarakat adalah pihak BPCB. Peran kepala desa dan ketua podarwis untuk mengarahkan, mendorong dan memberi motivasi terhadap masyarakat agar tetap berjalan dan berkembang desa wisata ini.

2. Tahapan pemanfaatan potensi dan ketrampilan masyarakat.

a. Upaya yang dilakukan dalam pemanfaatan potensi dan ketrampilan yang dimiliki untuk rintisan awal. Mengidentifikasi potensi, serta kendala pemberdayaan masyarakat terkiat dengan ketersediaan sumber daya budaya kawasan. Memetakan kebutuhan dan bentuk program pemberdayaan disesuaikan dengan kebutuhan masyarakat dan ketersediaan sumber daya pendukung. 
Mendorong terbentuknya lembaga

Pelestari Budaya lewat mekanisme bottom up, sebagai salah satu mitra local.

b. Pendampingan yang diberikan stakeholder dalam perintisan awal mula. Kajian yang dilakukan antara pihak BPCB bekerja sama dengan Pusat Studi Pariwisata Universitas Gadjah Mada.

3. Tahapan pengembangan desa wisata.

a. Berbagai bentuk upaya yang dilakukan untuk pengembangan desa wisata.Pihak Ketua Pokdarwis dan aparat setempat berusaha mengembangkan desa wisata dengan mendapatkan bantuan dari pemerintah. Seperti bantuan dana yakni dari PNPM , dari dana istimewa serta bantuan kerjasama dengan pihak luar baik itu dari pihak pemerintah atau swasta.

b. Pendampingan yang diberikan stakeholder dalam upaya pengembangan desa wisata.Pendampingan yang dilakukan salah satunya yakni dari PUSPAR UGM , BPCB , Jurusan Pariwisata Sekolah Vokasi UGM , Jurusan Pendidikan Teknik Busana dan Tata Boga, Universitas Negeri Yogyakarta, Balai Besar Kerajinan dan Batik Yogyakarta, PT Taman Wisata Ratu Boko. Secara garis besar, terdapat empat jenis pelatihan teknis yang diselenggarakan, yaitu Pelatihan Membatik, Pelatihan Membuat Suvenir, Pelatihan Kuliner dan Pelatihan Pemandu Wisata dan Pengembangan Usaha Perjalanan Pariwisata Budaya.

\section{Saran}

Mengingat masih kurangnya sumber daya manusia yang yang terampil dan terdidik dalam pengelolaan dan pemasaran desa wisata Plempoh, berikut ini beberapa solusi untuk membantu menyelesaikan persoalan tersebut :

1. Untuk warga setempat, perlu dilakukan pelatihan pelatihan untuk penyadaran pada generasi muda, agar paham dan mengerti mengenai kearifan lokal dan budaya desa.

2. Pihak Pokdarwis selaku pengurus dan pengelola harus mencoba lebih meningkatkan kreatifitas dan inovasi untuk pengelolaan atau menambah objekobjek wisata serta memperkuat kelompok masyarakat yang berhubungan dengan desa wisata. Paket wisata perlu dirancang agar menarik dengan harapan para calon wisatawan mau berkunjung dan mengakses liburan mereka di desa wisata Plempoh. Pemasaran produk wisata perlu diperluas melalui beberapa agen-agen perjalanan wisata yang berada di sekitar wilayah kota Yogyakarta, khususnya di agen-agen perjalanan di sekitar jalan Malioboro, Sosrowijayan dan Prawirotaman sebagai kampung wisatawan.

3. Dinas pariwisata hendaknya memberikan bantuan berupa materi maupun pelatihanpelatihan yang berhubungan dengan pengembangan pariwisata serta melibatkan warga dalam perencanaan 
pariwisata. Dengan diadakannya program pelatihan tersebut maka masyarakat desa dapat hidup lebih mandiri dengan mengandalkan keuntungan dengan kegiatan pariwisata di desa wisata Plempoh.

\section{Daftar pustaka}

Bogdan, Robert dan Steven Taylor, 1992. Pengantar Metode Kualitatif. Surabaya Usaha Nasional.

Freed W. Rigg dalam Badrul Munir, 2001. Babak Baru Pembangunan Daerah, Gagasan Dilema dan Tantangan. Mataram, NTB : Lekass.
Kurniawan, Boni. 2015. Desa Mandiri, Desa Membangun. Jakarta : Kementerian Desa, Pembangunan Daerah Tertinggal, dan Transmigrasi Republik Indonesia.

Martin Albrow. 2001. BIROKRASI. Tiara Wacana.

Moleong, Lexy J. (2011).Metodologi Penelitian Kualitatif. Bandung: PT Remaja Rosdakarya.

Slamet Santosa. 2006. Dinamika Kelompok. Jakarta: Bumi Aksara.

Sugiyono. 2016. Metode Penelitian Kuantitatif, Kualitatif dan Kombinasi (Mixed Methods). Bandung : Alfabeta.

Suharto, Edi. 2005. Membangun Masyarakat Memberdayakan Rakyat. Bandung: Refika Aditama

Peraturan Pemerintah Tentang Desa Tahun 2014 